\title{
ANALYSIS OF ENERGY EFFICIENCY OF OPERATING MODES OF ELECTRICAL SYSTEMS WITH THE TRACTION LOADS
}

\begin{abstract}
Innovative scenarios of reliable energy supply of transportation process aimed at reducing the specific energy consumption and increase energy efficiency of the systems of electric traction. The paper suggests innovative energy saving directions in traction networks of railways and new circuit solutions accessing traction substations in energy systems networks, ensure energy security of the transportation process. To ensure the energy security of rail transport special schemes were developed to propose the concept of external power traction substations, which would increase the number of connections to the networks of $220-330 \mathrm{kV}$, as well as the creation of transport and energy corridors, development of its own supply of electric networks of $110 \mathrm{kV}$ substations and mobile RP-110 $\mathrm{kV}$ of next generation. Therefore, the investment program of the structures owned by the Ukrainian Railways (Ukrzaliznytsia) need to be synchronized in their technological characteristics, as well as the criteria of reliability and quality of power supply with the same external energy investment programs. It is found that without any load on left or right supplying arm one of two less loaded phases of traction transformer begins generating specific modes in the supplying three-phase line. Thus, modes of mobile substation cause leakage in one of the phases of the supply line of traction transformers of active-capacitive current, and as a result generating energy in the main power line of $154 \mathrm{kV}$, which is fixed and calculated by electricity meters. For these three phase mode supply network is necessary to use 1st algorithm, i.e. taking into account the amount of electricity as the energy in all phases. For effective application of reactive power compensation devices in the AC traction power supply systems it is proposed to develop regulatory documentation on necessity of application and the order of choice of parameters and placement of compensation systems taking into account operation mode of power systems and the use of software systems with imitation of instantaneous interrelated schemes of transport loads. References 15, tables 3, figures 4.
\end{abstract}

Key words: energy security; railway transport; the process of transportation; networks of power systems; efficiency of modes; mobile traction substations.

В статье предложены инновационные направления энергосбережения в тяговых сетях железных дорог и новые схемотехнические решения присоединения тяговых подстанций $к$ сетям энергосистем, обеспечивающие энергобезопасность перевозочного процесса. Дано обоснование необходимости расчета тяговых подстанций по векторному методу трехфазного потребления энергии от подстанций НЭК «Укрэнерго». Библ. 15, табл. 3, рис. 4.

Ключевые слова: энергетическая безопасность, железнодорожный транспорт, процесс перевозок, сети энергосистем, энергоэффективность режимов, передвижные тяговые подстанции.

Introduction and problem definition. Analysis of changes in the structure of the energy balance of railways shows a strong tendency of orientation of their energy mainly in the power consumption. For example, for the previous period (1997-2012) the share of electricity has increased from $51 \%$ to $70.5 \%$ in the total energy balance of the railways. To known positive properties of electric energy (easy accessibility, portability, willingness to consume, etc.) added another, extremely important in modern conditions - lower cost of works and services, which are performed with the use of electric energy compared to the other main types of fuel and energy resources [1-5].

In Ukraine since 1950-s on the AC system $25 \mathrm{kV}, 50$ $\mathrm{Hz}$ electrified 5.5 thousand $\mathrm{km}$ (53\% landfill) of railways. World experience confirmed the undeniable advantages of the AC system before electrification system DC $3 \mathrm{kV}$. Currently, the share of electrified portions of the total operational length of railways is $47.3 \%$, while the share of electric traction in the overall turnover equal to $91.2 \%$. However, the effects of the economic crisis significantly reduced the rate of electrification of railways in 2014-2016. As a result, the most important electrified line Kharkiv - Poltava - Kremenchug - Znamenka works internally powered modes of traction network from mobile substations [5-8].

One of the most urgent issues of energy transport process is the effective implementation of the traction electricity reserve capacity power supply of electrified railways AC roads. Ways of realization of reserve capacity are different. If the main focus of the railways of the advanced economies is placing on the traction substations stationary traction reserve units, the railways of Ukraine, this problem is solved by the mobile reserve of traction substations. Recently put into operation during the period of sustained growth in traffic. In the fall of traffic they may be involved in other areas which are expected to increase in traffic. Naturally, such a «flexible» reservation system must be linked in circuit and regime system with external power supply.

In order to reduce costs for the electricity industry all the railways of Ukraine carried out the supply of electricity to consumers at regulated tariffs, which saves hundreds of million UAH the procurement of electricity (in 2014 - 631 million UAH). Advantages of the wholesale electricity market, electricity purchases are obvious, but there are some features of payment for electricity in conditions of forced modes of electric traction networks with mobile traction substations [2-5].

The pace of aging power units at the existing funding gap continues to outpace reconstruction. The length of electrified lines of the landfill, which operated over the average period of time (40 years) increased to $6393 \mathrm{~km}$ or $62.3 \%$ in 2012 , and today this figure is closer to $6,820 \mathrm{~km}$ or $67 \%$. With a lifetime of over 30 years

(C) V.O. Bondarenko, I.V. Domanskyi, G.N. Kostin 
232 stationary (78\% of the total) and 10 mobile traction substations are working. At the present time requires a complete reconstruction of more than $50 \%$ of the expanded length of the catenary and traction substations. To stabilize the situation need to increase the pace of renovation of the traction power supply units in the period from 2016 to 2020 every year at least $600-670 \mathrm{~km}$ of catenary and traction substations $10-15$, with an average financing needs for one substation about 50 million UAH $[1,7,8]$.

Reasons of the low efficiency of power lie in the technical, economic, organizational processes: the degraded state of electrical networks due to wear and tear; unbalance load lines phases; unbalance modes of transmission lines; the impact of energy flows in the common elements of the network (the effect of the loss of non-linearity) uncompensated reactive power flows.

Therefore, the question of the substantial increase in the volume of works on modernization, improve the reliability and efficiency of the traction power supply, as well as the electrification of new railway lines belongs now to the most important priorities of development of the railway energy of Ukraine.

The goal of the paper is analysis and development of ways to improve the energy efficiency of modes of electrical systems with traction loads and the rationale for the calculation of traction substations for the vector method of three-phase energy consumption from substations of the National Energy Company «Ukrenergo».

1. Energy efficiency analysis of traction and external power supply for electrified line Poltava Kremenchug - Alexandria. The general lack of circuit connections of traction substations (TS) of electrified areas for the period 1993-2011 lies in the fact that virtually all substation joined the network of $110 \mathrm{kV}$ of regional power companies and a number of them to such networks $110 \mathrm{kV}$ which connect different energy system.

The choice of external power supply scheme of TS (Fig. 1) is made in accordance with the "Standards for technological design of energy systems and electric networks of $35 \mathrm{kV}$ and above» and new chart-technical solutions join the TS to the power system networks, which proved in $[5,9]$ used in railway electrification.

The source of external power supply of traction substation is a substation of $330 \mathrm{kV}$ North and Dnieper power systems. 330/110 kV substations Poltava was introduced into operation in 1964 and 1997. Currently, the substation is equipped with 4 auto-transformer, two 125 MVA and two 200 MVA. Outdoor switchgear (OSG) 330 $\mathrm{kV}$ substations Poltava performed under the scheme 33010 «transformer - bus lines with the connection by two switches». At this voltage are due to Zmiev thermal power plant, substations with 750/330 kV Severoukrainskaya and 330/154 kV Kremenchug.

$110 \mathrm{kV}$ OSG Poltava has four sections, two sectional and two co-located with the bypass section switch. The distribution of electrical power from the TS Poltava 110 $\mathrm{kV}$ voltage is carried to consumers of Poltava city and the Poltava region, and traction substations.
OSG $154 \mathrm{kV}$ traction substation Alexandria has three sections $154 \mathrm{kV}$ bus on which power is supplied from the substation «North» and the substation Znamenka. The distribution of electrical power from the TS Alexandria on voltage $154 \mathrm{kV}$, substation Konstantinovka made to consumers, the substation «Neftianik» and substation Morozivka.

At TS Alexandria in 2009 it was put into operation three continuously adjustable settings transverse capacitive compensation (CS) (manufacturer ČRD ELEKTROTEXNIKA), with total capacity of 18.4 Mvar. In the phase $A$ and phase $B$ included adjustable installation CTK with capacitors type CUEFS 23-8.7/600/ $\mathrm{WF}$ and compensating reactors and decompensating respectively KTL-182/155 and KTL-192/210 with 7609 of $Q_{A}=7609$ kvar and $Q_{B}=7565$ kvar. Unregulated installing $\mathrm{KU}$ with capacitors KЭK1-1,05-63-1У1 and reactor $\Phi$ POM-3200/35У 1 , capacity $Q=5699$ kvar is included in the phase $A$ or $B$. To ensure the compensation (decompensation) of reactive power and filtering of higher harmonic components of voltage and current general scheme applies dynamic compensation, in which the converter COMPACT system provides adjustment of the value of the phase current of decompensating reactors. The basis of this system is the semiconductor converter unit which includes optothyristors with protective resistor-capacitor elements and signaling unit.

Before installing CS average daily electricity consumption of traction substation in 2009 was $S=$ $=250-j 80 \mathrm{MVA}, \operatorname{tg} \varphi=0.32$. For such a load, installed capacity capacitors (18.4 Mvar) exceed correctly calculated by the reactive power, voltage mode, unbalance, harmonics several times [10-15]. It is possible with such a huge power capacitors thyristors fully open permanently. It is interesting to know their real condition and mode of operation. Analyzing the state of the CS in the evaluation of energy losses in the first place should pay attention to the installation of the filter with oil-filled reactors ФPOM-3200/35Y1. In addition to the increased complexity of the maintenance of these reactors, they are characterized by higher energy losses. In particular, only the power loss in the steel reactor cores is $10.5 \mathrm{~kW}$.

Technical and economic calculations show that in the current application smoothly regulated CS plants due to the large capital investment that determines the large payback period (10-15 years) for the traction network of national railways.

In general, the following measures can be applied to improve the efficiency of the heterogeneous network: division of low voltage network, the use of longitudinal capacitive compensation in high-voltage lines, inclusion of booster transformers in the branch networks of different nominal voltages. The most advantageous solution is determined by the feasibility study on the simulation models based on modes of supply of power systems [3-5]. Currently, the contact area network Kobelyaki - Kremenchug - Alexandria partitioned neutral accents and is a long cantilever sections with single feed. 
a)

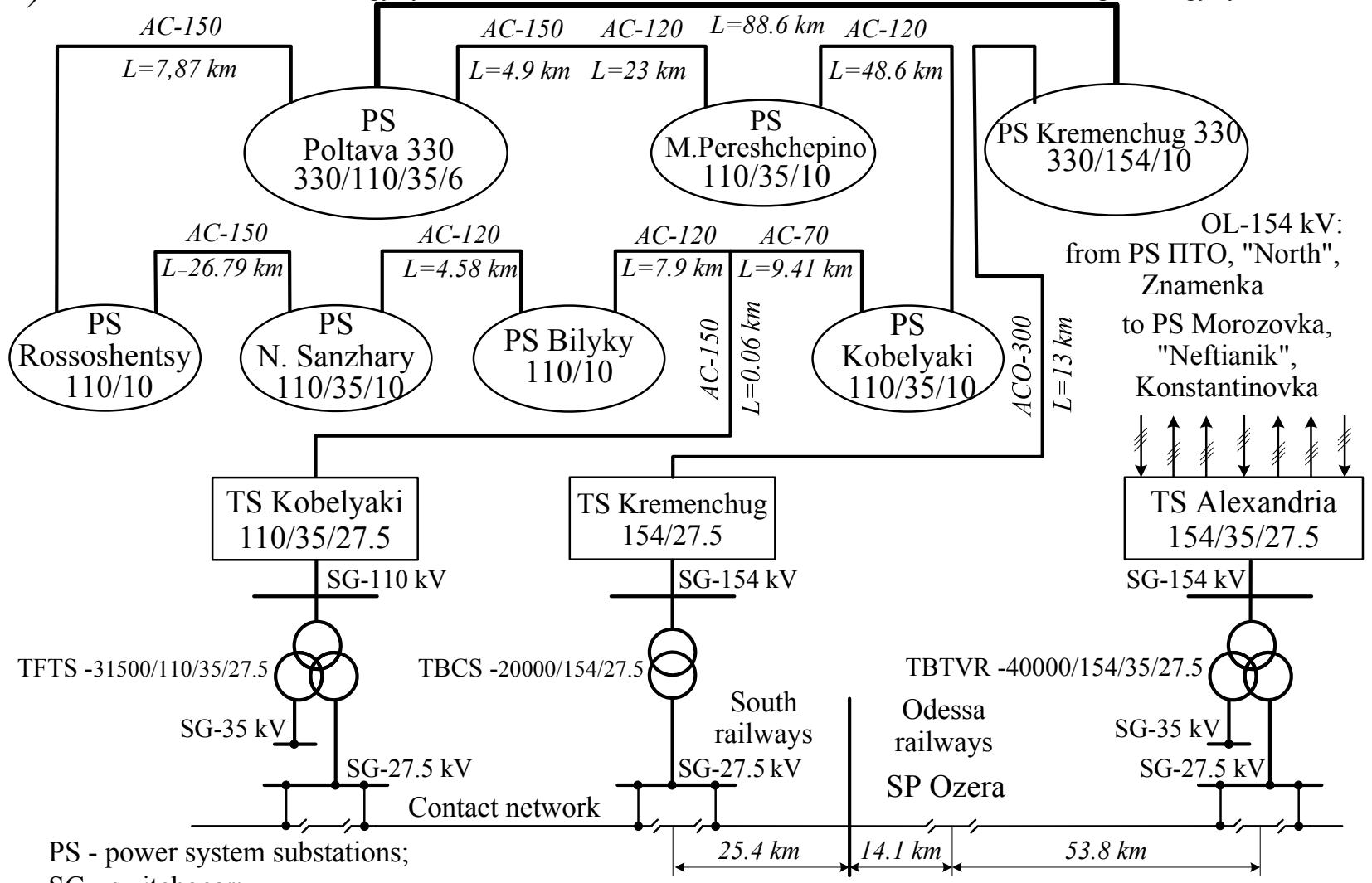

$\mathrm{SG}$ - switchgear;

OL - overhead lines of power systems; $\quad$ AC, ACO - type of OL wire; $\quad$ SP - sectioning post

b)

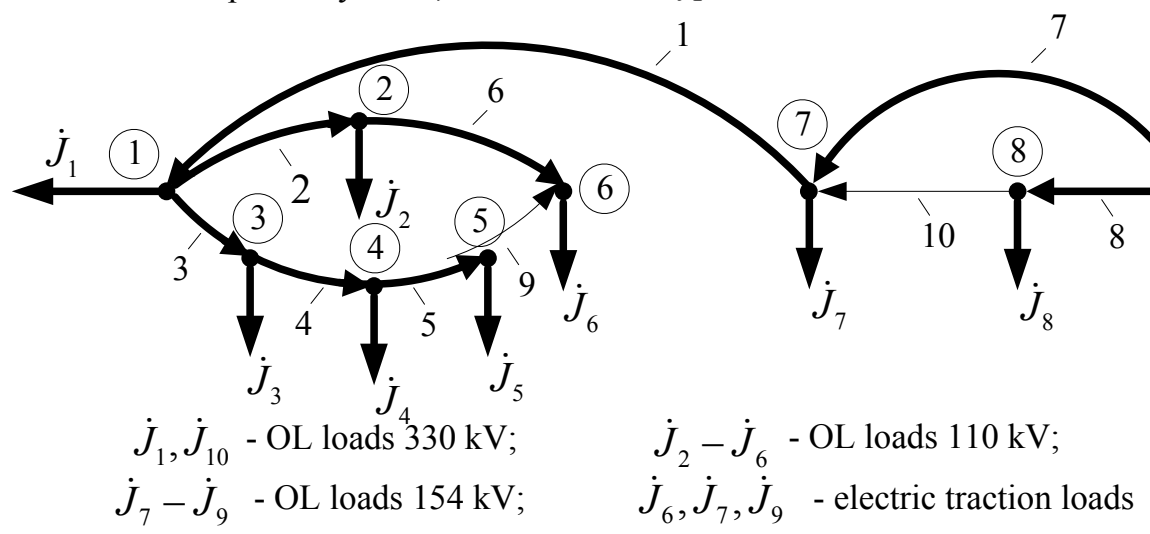

Fig. 1. The scheme of external power supply of traction substations at the junction of South and Odessa railways and its directed graph (here: TFTS - three-phase transformer with air-filters and three windings for mobile substations; TBCS - three-phase transformer, the oil cooling with blown and natural circulation of oil for mobile substations; TBTVR - three-phase transformer, cooling with blown and natural circulation of oil; three windings; with automatic load voltage regulation for rail, electrified with alternating current, rated power of $40,000 \mathrm{kVA}$, voltage class $154 \mathrm{kV}$ )

Parallel running electrical traction networks $27.5 \mathrm{kV}$ and the network 110, 154, $330 \mathrm{kV}$ (Fig. 1) are heterogeneous and power transmission it happens when you increase the value of active power and energy losses, that is, at a reduced cost-network operation as a whole. Heterogeneity of traction power systems and supply chains leads to an increase in the equivalent resistance $R_{e q}$ at the power transmission path. Thus, if for a homogeneous network, active equivalent resistance $R_{\text {eqo }}$ will be equal $R_{e q o}=\frac{r_{1} \cdot r_{2}}{r_{1}+r_{2}}=\frac{r}{2}$, than for inhomogeneous one which graph is presented in Fig. 1,b
$R_{e q}=\operatorname{Re} \frac{\underline{Z}_{1} \cdot \underline{Z}_{2}}{\underline{Z}_{1}+\underline{Z}_{2}}$, and increase of the active resistance can be determined by the following expression

$$
\frac{R_{e q}-R_{e q o}}{R_{e q o}}=\frac{\left(\xi_{1}-\xi_{2}\right)^{2}}{2+\left(\xi_{1}+\xi_{2}\right)^{2}},
$$

where $\xi_{1}, \xi_{2}$ are the ratios of reactance to active resistance of the corresponding graph branches.

Calculations with real values of resistance by the expression (1) lead to the conclusion that, in parallel to the network 110 and $27.5 \mathrm{kV}, 154 \mathrm{kV}$ and $27.5 \mathrm{kV}$ have to expect an increase in the equivalent resistance 
by $15-20 \%$. Consequently, at $15-20 \%$ power loss will be large.

The main load of the network is the system load $\dot{J}_{1}$ and $\dot{J}_{10}$, loads of traction substations $\dot{J}_{6}, \dot{J}_{7}, \dot{J}_{9}$ have significantly less value. Count circuit branches, the reduced voltage to one have different ratios of reactance to active resistance $\xi=x / r$. For a given circuit condition heating low voltage network wires limit the capacity of the network. Part of the network of higher voltage $(330 \mathrm{kV}, 154 \mathrm{kV})$ underload, as part of a network with a lower voltage is overloaded. The flow of power is on the branches 6 and 10 of the graph circuit.

Heterogeneity of parallel networks 330, 154, 110, $27.5 \mathrm{kV}$, the specific modes of operation minimizes the benefits of closed networks, is the large power supply reliability, better quality of electricity and if you can not take into account for traction network power flow in fee, will inevitably use console power circuits.

Traction substation Kobelyaki and Kremenchug are powered by the North energy system and Alexandria from the Dnieper energy system. The scheme of parallel operation and partitioning traction network is shown in Fig. 2. The inclusion of traction substations for parallel operation will inevitably lead to power flows on the network even when the traction according to the normalized values of primary voltage due to differences in their capacities.

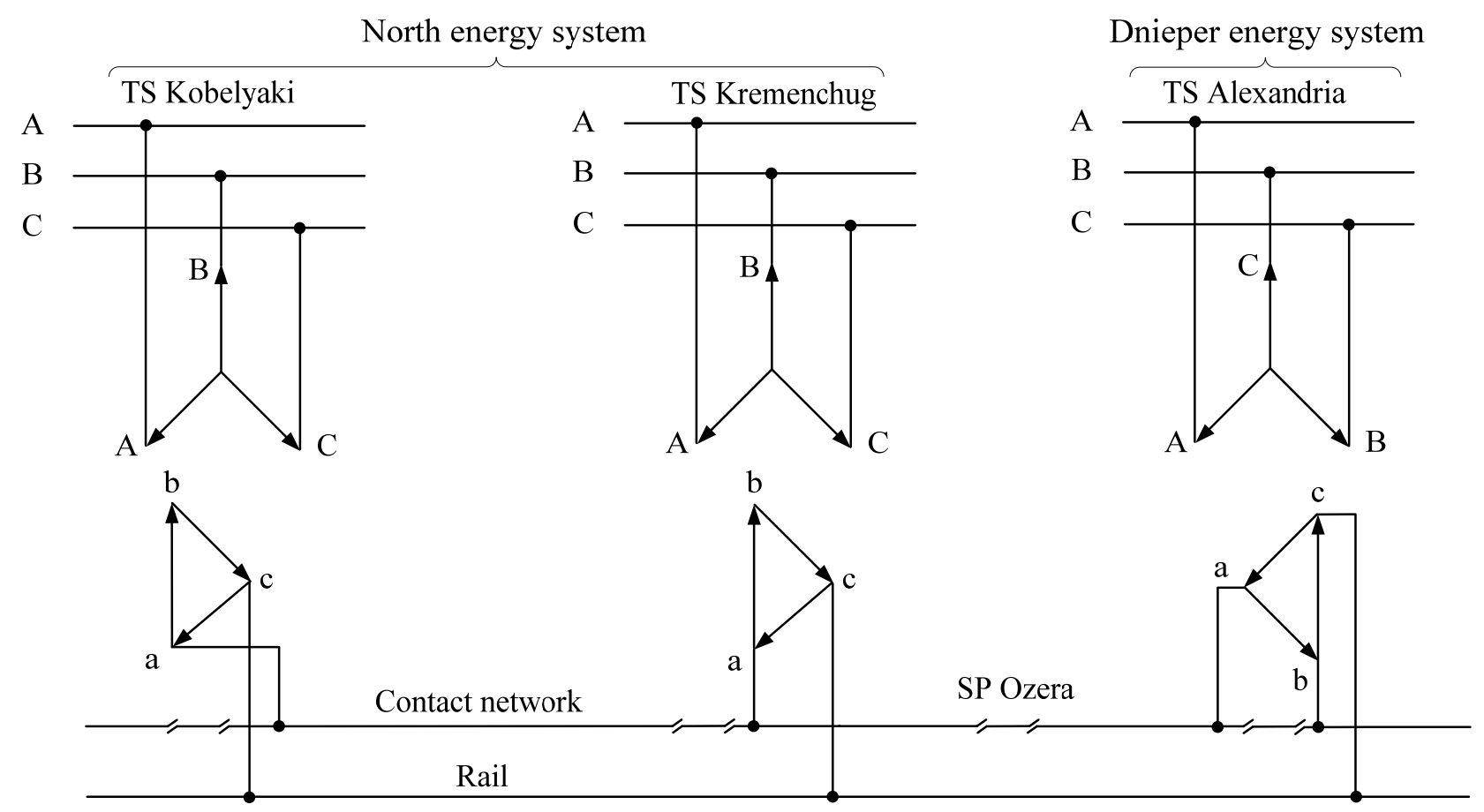

Fig. 2. The scheme of parallel operation of traction substations

Taking into account that the total power consumption of traction substation consists of the consumption of electricity for traction power, losses and power flows on the traction network, we can offer a formula for determining the flow

$$
W_{\text {over }}=W-\Delta W-W_{t s}=\sum_{i=1}^{n}\left(I_{s h i}^{*} \dot{U}_{t i}-\Delta \dot{S}_{i}\right)-W_{t s i} \text {, }
$$

where $W$ is the comprehensive energy consumption of traction substation; $W_{T S}$ is the electricity consumption for train traction; $\Delta W$ is the power loss in the traction networks; $I_{S h i}$ is the conjugate complex of instant currents in shoulders of power traction substation; $\dot{U}_{t i}$ is the the instantaneous voltage on the tires traction substation; $n$ is the number of solved instant schemes in simulations electrotraction networking modes.

A preliminary assessment of the scheme traction power network and the selection of the scheme, which allows to approach the power-saving mode of the traction power supply system is determined by modeling power flow and energy loss. At the same time the implementation of the automated system of commercial electric power accounting on all railways of Ukraine allows today to use these energy meters traction substations and implement the actual definition of the electricity costs for various power schemes. Last modification counters at traction substations (with appropriate software), and can measure power loss in the zone between substations. By analyzing this information, power dispatcher can select an energy-saving power supply circuit [5].

2. Forced modes of mobile traction substations and power system supply lines. Reality today is such that, almost without reserve, mobile substation for a long time working instead of fixed-to-congested areas, and some super-long cantilever sections loaded with only one arm power, which leads to a sharp current unbalance traction transformers phases (least loaded are two phases) and finally to increased energy losses $[5,6]$. 
In May 2014 it was put into operation a mobile substation «Traction Kremenchug» which is attached directly to the main power grids of North grid, namely the PS-330 «Kremenchug». Modes of her work defined the technical specifications, including power and modes with long cantilever sections one shoulder power («lagging» or «advanced» phase). [8] It is necessary for the implementation of the transportation process on the condition of ensuring the minimum level of tension in the electric rolling limiting sections $(U=21 \mathrm{kV})$. As shown below, such mobile substation modes cause flow in a single phase traction supply line transformers activecapacitive current and as a result, the generation of energy in the mains power line $154 \mathrm{kV}$, which is fixed and the calculated electricity meters. According to the theory of electrical networks and the existing rules of electric power metering, for such modes of three-phase mains supply requires the use of a vector method, i.e., metering of electricity as the amount of energy in all phases, taking into account the sign.

It is known that on the roads of single-phase AC power traction network is usually carried out by a threephase transmission line through transformers connected to this or that scheme [3]. Of all the possible connection scheme of the three-phase transformers, the most widely used on the railways of Ukraine got a scheme in which the traction winding is connected in a triangle. When connecting the traction windings delta loading, though not identical, but all three phases of high voltage lines. It is possible to power district load from a third transformer winding voltage of 10 or $35 \mathrm{kV}$. The primary winding of the three-phase transformer is always connected in a star. When connecting the traction winding triangle is no circuit for zero-sequence fundamental frequency currents. In this case, much less disturbing effect of high-voltage line on the communication line. These circumstances had a decisive influence on the fact that the traction winding three-phase transformer is connected in delta. A more uniform load three-phase transmission line phases is achieved when powered traction substations of all three phases of the transmission line. In this case, the traction network section of the left and right of the substation fed by various transmission line phase and consequently have a voltage out of phase with each other.

When considering schemes of traction substations for the positive direction of the currents $\left(\dot{I}_{A}, \dot{I}_{B}, \dot{I}_{C}\right)$ to the transmission line, branches from the transmission line to the substation, and also in the feeders that feed a power train $\left(\dot{I}_{L}, \dot{I}_{R}\right.$ and $\left.\dot{I}_{P}\right)$, will take direction from the feeding center to the consumer. For the positive direction of currents in electric locomotives will take direction from the conductor to the contact rail. For the power supply circuit (Fig. 3) combined vector diagram of voltages and currents in the particular case (the least loaded are two phases) shown in Fig. 4. When constructing diagrams accept transformation ratio equal to one and neglect the idling current and voltage losses in the windings. Then, the voltages $\dot{U}_{A}, \dot{U}_{B}$ and $\dot{U}_{C}$ and, accordingly, voltages $\dot{U}_{a c}, \dot{U}_{b a}$ and $\dot{U}_{c b}$ will be provided and the same vectors (Fig. 4). The current vector $\dot{I}_{L}$ (left side) received the voltage should be oriented with respect to the voltage vector $\dot{U}_{a c}$. In the vector diagram shows the current $\dot{I}_{L}$ shifted from «their» voltage at a certain angle $\varphi_{L}$. The current vector $\dot{I}_{R}$ (coming from the substation to the right) in the direction shown in Fig. 3, focused on the vector of «their» voltage $-\dot{U}_{c b}$ opposite to the voltage $\dot{U}_{c b}$ shown on the diagram (Fig. 4). Laying voltages on the chart $-\dot{U}_{c b}$ (shown in dotted line), it can relatively displaced by a certain angle $\varphi_{R}$ applied $\dot{I}_{R}$ current vector. Knowing $\dot{I}_{L}$ and $\dot{I}_{R}$ it is easily find the current $\dot{I}_{P}$ in the wire attached to the rail as the magnitude of the counterbalance (as well $\dot{I}_{L}+\dot{I}_{R}+\dot{I}_{P}=0$ ), and the phase current transformer [3]:

$$
\dot{I}_{a}=2 / 3 \dot{I}_{L}+1 / 3 \dot{I}_{R} ; \dot{I}_{b}=1 / 3 \dot{I}_{R}-1 / 3 \dot{I}_{L} ; \dot{I}_{c}=-2 / 3 \dot{I}_{R}-1 / 3 \dot{I}_{L} .
$$
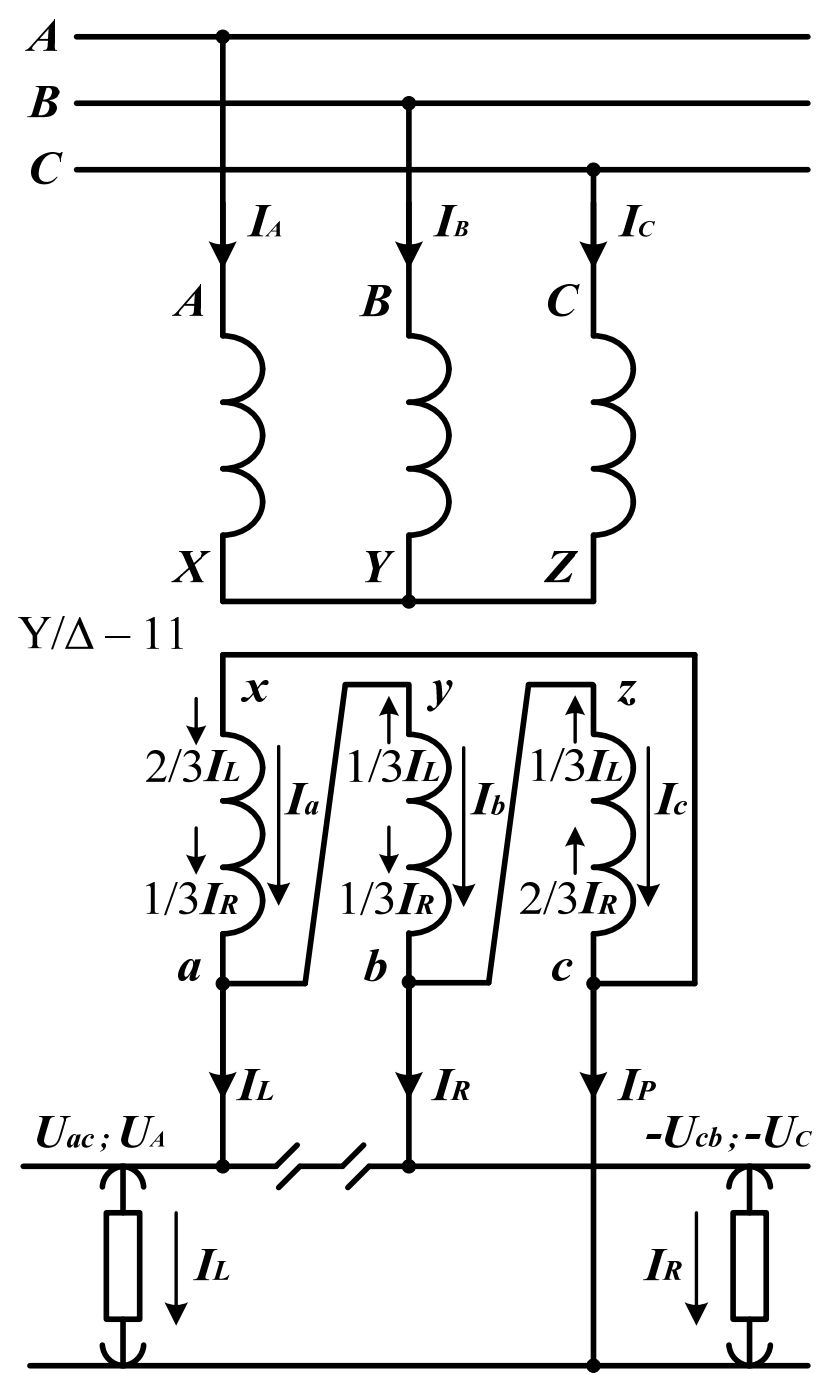

Fig. 3. Feeding diagram of the traction power supply of single-phase current using three-phase transformer connected according to the scheme $\mathrm{Y} / \Delta-11$

Left feeder zone to the current $\dot{I}_{L}$ powered by voltage $\dot{U}_{a c}$. This voltage is generated in the winding ah and windings $y b z c$ (where it is obtained by adding the voltages of the two geometric windings $b y$ and $c z$ ). But $a x$ winding resistance is half the resistance of the other two windings connected in series. Therefore, the current $\dot{I}_{L}$ is 
divided between generating voltage $\dot{U}_{a c}$ windings in the ratio of $2: 1$. Similarly, current $\dot{I}_{R}$ is shared. It can be noted (Fig. 3) which is the least loaded phase is the phase of the triangle, which is not directly connected to the rails. In this case, when one of the loads, $\dot{I}_{L}$ or $\dot{I}_{R}$, equal zero, two phases are loaded least.
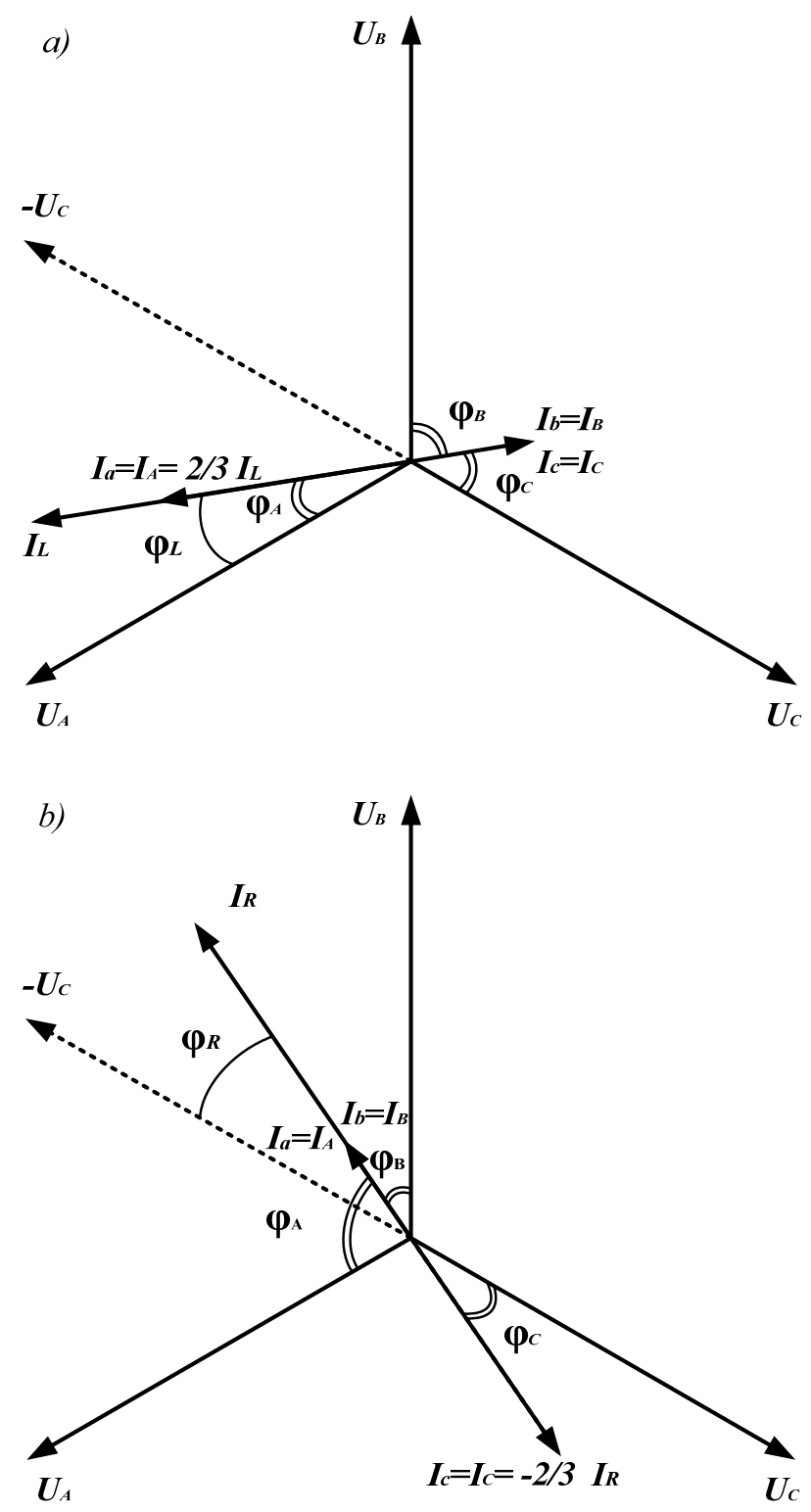

Fig. 4. Vector diagram to determine phase currents of the threephase transformer for the particular case: $a-$ load $\dot{I}_{R}$ of the feeding right side equal zero; $b-$ load $\dot{I}_{L}$ of the feeding left side equal zero

Let us consider in more detail the special case where the least loaded are two phases, for example, when powered traction load only the left shoulder «lagging» phase (Fig. 4,a) or only the right shoulder «advanced» phase (Fig. 4,b). When powered load left shoulder $\dot{I}_{L}$ «lagging» phase (Fig. 4,a) the angles of phase shift between the currents $\dot{I}_{A}, \dot{I}_{B}$ and $\dot{I}_{C}$ and the voltages $\dot{U}_{A}$, $\dot{U}_{B}, \dot{U}_{C}$ is significantly increased. Note that $\varphi_{A}=\varphi_{L}$, current $\dot{I}_{B}$ lags the voltage $\dot{U}_{B}$ by an angle $\varphi_{B}$, and $\dot{I}_{C}$ leads the voltage $\dot{U}_{C}$ by an angle $\varphi_{C}$. Thus, one of the leastloaded traction of transformer phase begins to generate current in the supply network. When powered right shoulder load $\dot{I}_{R}$ «advanced» phase (Fig. 4,b) $\varphi_{C}=\varphi_{R}, \dot{I}_{B}$ current leads the voltage $\dot{U}_{B}$, and now this phase traction transformer generates a current in the supply network.

In the presence of the load on the district may not have the traction substations and low thrust loads this mode, but for mobile substations $(10 \mathrm{kV}$ for regional consumers are not always designed) are inevitable.

Experimental investigations were carried out for normal and forced modes of electric traction network. Forced (provisional) mode in a mobile operating conditions traction substation considered mode where plot Kremenchug - Ozera supply voltage of $27.5 \mathrm{kV}$ phase $A$ and phase $B$ is in an idle mode. Normal mode will assume a mode in which the traction substation feeds Kremenchug - Ozera (phase $A$ ) and Kremenchuk Kobelyaki (phase $B$ ). It was found that the power of the mobile traction substation «Traction Kremenchug» 20 MW does not allow transportation process on the console section of traction network length of $39.5 \mathrm{~km}$ Kremenchug - Ozera normally due to the need to ensure the minimum level of $21 \mathrm{kV}$ voltage on the pantograph of electric rolling of limiting haul.

The presented results confirm that in the reverse direction of energy in the least loaded phase $B$ from the higher voltage is the result of bias currents in the winding of a traction transformer $y b$ forced mode mobile substation «Traction Kremenchug».

Experimental investigations have confirmed the cause of the generation mode in phase $B$ of the OL $154 \mathrm{kV}$ and traction load requirements of GOST 13109-97 «Power quality limits in public electrical networks».

The absence of power generation by the traction load is confirmed by experimental measurements at the input of $27.5 \mathrm{~kW}$ traction transformer substation mobile «Traction Kremenchug» under different loads on the feeder zone Kremenchug - Ozera (Table 1). Thus, the experimental research results confirm the theoretical study on the use of the vector algorithm, taking into account the amount of electricity when powered mobile traction substations of backbone electric grids of the National Energy Company «Ukrenergo».

3. Evaluation of electric energy in the traction substations. It is known that at the traction substations of electrified railways of commercial electric power accounting devices should be installed at the boundary equipment accessories, i.e. at the level of the power supply traction transformers. However, the majority of traction substations of electric energy accounting is conducted at low and medium voltage. In this case the loss of electrical energy in traction and stepdown transformers are determined by calculation. 
The unit of electric energy at levels low and medium voltage due to the lack of measuring transformers of current and voltage at a high voltage transformer substations with the old type of stationary, mobile and on they do not provide even a project.

Table 1

Experimental investigations on the feeder $27.5 \mathrm{\kappa V}$ of the TS «Traction Kremenchug»

\begin{tabular}{|c|c|c|c|c|c|c|c|c|c|c|c|c|}
\hline No. & $\begin{array}{c}\text { Measur. } \\
\text { No. }\end{array}$ & $P_{a}, \mathrm{~kW}$ & $P_{b}, \mathrm{~kW}$ & $Q_{a}, \mathrm{kvar}$ & $Q_{b}, \mathrm{kvar}$ & $U_{a b}, \mathrm{~V}$ & $U_{c a}, \mathrm{~V}$ & $U_{b c}, \mathrm{~V}$ & $I_{a}, \mathrm{~A}$ & $I_{b}, \mathrm{~A}$ & $\varphi_{a}$ & $\varphi_{b}$ \\
\hline 1 & 32 & 2604.3 & 60.9 & 577.5 & 38.9 & 102.6 & 94.6 & 86.2 & 99.0 & 2.6 & 133.2 & 272.6 \\
\hline 2 & 36 & 3313.8 & 64.7 & 498.6 & 24.3 & 102.4 & 95.3 & 84.7 & 122.4 & 2.5 & 128.9 & 260.8 \\
\hline 3 & 37 & 4513.3 & 64.8 & 156.0 & 20.2 & 101.6 & 95.0 & 83.4 & 162.1 & 2.5 & 122.7 & 257.2 \\
\hline 4 & 41 & 4868.1 & 63.5 & -1004.9 & 24.9 & 101.3 & 95.7 & 83.6 & 179.3 & 2.6 & 108.3 & 261.5 \\
\hline 5 & 40 & 6391.0 & 61.4 & -1944.8 & 24.8 & 100.2 & 95.3 & 82.6 & 239.6 & 2.5 & 103.1 & 262.2 \\
\hline 6 & 33 & 8250.0 & 62.4 & -2558.6 & 17.8 & 99.3 & 95.6 & 82.3 & 306.6 & 2.5 & 102.9 & 255.3 \\
\hline 7 & 34 & 8789.0 & 63.0 & -2328.2 & 18.9 & 99.0 & 96.3 & 81.1 & 321.4 & 2.6 & 104.6 & 256.6 \\
\hline 8 & 25 & 10142.0 & 62.9 & -3898.4 & 27.6 & 98.3 & 97.2 & 81.7 & 383.8 & 2.8 & 98.9 & 263.1 \\
\hline 9 & 21 & 13013.0 & 186.4 & -5024.8 & 78.8 & 96.8 & 96.3 & 78.2 & 485.4 & 8.1 & 99.1 & 263.1 \\
\hline 10 & 10 & 14855.5 & 203.7 & -5802.5 & 70.0 & 95.6 & 97.1 & 78.0 & 555.0 & 8.8 & 98.0 & 258.4 \\
\hline 11 & 11 & 16439.5 & 218.1 & -6666.0 & 70.7 & 94.8 & 96.6 & 76.5 & 615.2 & 9.5 & 98.2 & 258.3 \\
\hline 12 & 14 & 18155.5 & 227.0 & -6886.0 & 78.8 & 94.0 & 96.9 & 74.3 & 673.6 & 10.2 & 99.3 & 259.2 \\
\hline 13 & 19 & 21235.5 & 246.5 & -7804.5 & 87.8 & 92.5 & 97.9 & 72.4 & 781.0 & 11.4 & 99.8 & 259.8 \\
\hline
\end{tabular}

Note. 9-13 - short-term connections of the phase $B$ to feed traction network of the feeder zone Kremenchug - Kobelyaki (current transformer coefficient $-1000 / 5$, account ratio -55000 ).

Payment points with wholesale electricity market for electricity placed in cell No. 2 of OSG-154 kV of substation PS-330 «Kremenchug». Current account for traction feeders mounted on the contact network and the technical account - on the feeder of $27.5 \mathrm{kV}$ power transformer of the mobile substation «Traction Kremenchug». Comparative analysis of the volume purchased and released electric energy for the period May - November 2014 indicates the presence of imbalance which is more than $10 \%$ (Table 2,3). Analysis of the data (see Table 2,3) shows that the calculation of flow of electrical energy at the point of calculation intentionally or erroneously on the following principle.

Table 2

Reported data of release and reception of power of the TS «Traction Kremenchug»

\begin{tabular}{|c|c|c|c|c|c|c|c|}
\hline \multirow{2}{*}{ Month } & \multicolumn{2}{|c|}{$\begin{array}{l}\text { Electrical energy volume at the OL } 154 \mathrm{kV} \text {, thousand } \\
\mathrm{kW} \cdot \mathrm{h}\end{array}$} & \multirow{2}{*}{$\begin{array}{c}\text { Reception on } \\
\text { buses } \\
27.5 \mathrm{kV}, \mathrm{kW} \cdot \mathrm{h}\end{array}$} & \multicolumn{2}{|c|}{$\begin{array}{l}\text { Calculated losses, } \\
\text { thousand } \mathrm{kW} \cdot \mathrm{h}\end{array}$} & \multicolumn{2}{|c|}{$\begin{array}{c}\text { Unbalance OL } \\
154 \mathrm{~kW}\end{array}$} \\
\hline & Release & Generation & & $\begin{array}{l}\text { in the } \\
\text { transformer }\end{array}$ & $\begin{array}{l}\text { OL } \\
154\end{array}$ & $\begin{array}{c}\text { thousand } \\
\mathrm{kW} \cdot \mathrm{h}\end{array}$ & $\%$ \\
\hline May & 3270.6 & 406.8 & 2855.7 & 27.082 & 1.686 & 386.115 & 11.8 \\
\hline June & 3643.2 & 457.2 & 3172.3 & 27.877 & 2.223 & 440.758 & 12.1 \\
\hline July & 3965.4 & 472.68 & 3472.6 & 29.541 & 2.557 & 460.697 & 11.6 \\
\hline August & 4215.6 & 526.86 & 3666.3 & 30.629 & 2.904 & 515.796 & 12.2 \\
\hline September & 4726.8 & 600.48 & 4100.5 & 29.427 & 3.881 & 593.009 & 12.5 \\
\hline October & 5238.0 & 635.04 & 4573.2 & 31.544 & 4.594 & 628.704 & 12.0 \\
\hline November & 5455.8 & 671.58 & 4751.7 & 31.961 & 5.218 & 666.926 & 12.2 \\
\hline
\end{tabular}

Table 3

The balance sheets of release and reception of power of the substation PS-330 Kremenchug

\begin{tabular}{|c|c|c|c|c|c|}
\hline \multirow[b]{2}{*}{ Month } & \multicolumn{3}{|c|}{ Received on buses $154 \mathrm{kV}$, thousand $\mathrm{kW} \cdot \mathrm{h}$} & \multirow{2}{*}{$\begin{array}{l}\text { Received from bus } 154 \mathrm{\kappa B}, \\
\text { thousand } \mathrm{kW} \cdot \mathrm{h}\end{array}$} & \multirow{2}{*}{$\begin{array}{l}\text { Buses } 154 \mathrm{KV} \text { unbalance, } \\
\text { thousand } \mathrm{kW} \cdot \mathrm{h}\end{array}$} \\
\hline & $\begin{array}{c}\text { From } \\
\text { autotransformer }\end{array}$ & $\begin{array}{l}\text { From other } \\
\text { sources }\end{array}$ & $\begin{array}{l}\text { From traction } \\
\text { substation }\end{array}$ & & \\
\hline May & 169862.4 & 4908.6 & 406.8 & 175132.4 & -361.8 \\
\hline June & 163753.2 & 4307.4 & 457.2 & 168269.4 & -208.8 \\
\hline July & 185108.4 & 8172.0 & 473.4 & 193366.8 & -86.4 \\
\hline August & 223824.6 & 543.6 & 527.4 & 224535.6 & -167.4 \\
\hline September & 206530.2 & 1656.0 & 599.4 & 208222.2 & -64.8 \\
\hline October & 212432.4 & 6161.4 & 635.4 & 218410.2 & -421.2 \\
\hline November & 200809.8 & 7444.8 & 671.4 & 208215.0 & 39.6 \\
\hline
\end{tabular}


Installed at the design point per phase electricity meters are set to account in both directions, and in determining the amount of flow of electricity accounted for the volume of electricity supplied by each phase separately. Thus, the presence of lasing at any given volume of phase calculation is excluded. As a result of this calculation railroad monthly, starting in May 2014 (after OL $154 \mathrm{kV}$ commissioning and mobile traction substation «Traction Kremenchug»), purchases of electricity by nearly 500 thousand $\mathrm{KW} \cdot \mathrm{h}$ more than the consumer supplies. With a monthly volume flow on the OL $154 \mathrm{kV}$ 4000-4500 thousand $\mathrm{KW} \cdot \mathrm{h}$ OL loss exceeds $10 \%$ of normative losses at the rate of class 1 power purchase 3.66-3.86\%. As a result of the imbalance between the amount of electric energy that was allotted to the substation PS-330 «Kremenchug», and the actual amount received by railway on TS «Traction Kremenchug» for the period May-November 2014 amounted to 3771 thousand $\mathrm{KW} \cdot \mathrm{h}$. However, it should be noted that in determining the amount of unbalance of tires $154 \mathrm{kV}$ Substation PS-330 «Kremenchug» and substation as a whole calculation is carried out taking into account of the full phase mode electricity flow at all points in the account, including taking into account the phase $B$ of generation in the OL 154 «Traction Kremenchug». Thus, the calculation algorithm in the balance of the substation PS-330 «Kremenchug» is different from the volume calculation algorithm for suppliers of electrical energy connected to this substation, which is contrary to the rules.

\section{Conclusions.}

1. Analysis of the electrical system with loads traction shows that to improve their energy efficiency needs a fullscale program of modernization. The investment program included in the structures of JSC «Ukrzaliznytsia» must be synchronized on the technological parameters, as well as the criteria of efficiency and quality of power supply with the same external energy investment programs.

2. In the analysis of risks and threats to energy supply process traffic of railways from the external power supply is suggested to use a system of rating assessments of energy security for all of the following indicators: the reliability of power supply system taking into account the high measure of depreciation of fixed production assets of the energy economy of the region; power ratio of the amount of power and bandwidth interconnections to the maximum electrical load of consumers in the region; power flow estimation in electric traction network and their account in fees for payments for electricity.

3. To improve power quality, reliability and security of power supply and reduce the cost and time of construction of traction substations new schemes and technical solutions of external power supply are proposed, which are based on joining to networks of the National Energy Company «Ukrenergo» (220-330 kV) and use of reactive power controlled compensation devices.
4. As a result of theoretical and experimental investigations of forced modes of mobile traction substation "Traction Kremenchug» it is found that in the absence of the left or right shoulder load power of traction network one of the two least-loaded traction transformer phases causes flowing in one phase of the supply line of active-capacitive reverse current that is fixed by calculated electric meters with phase segregated algorithm calculations as generating the least loaded phase. Such modes of power supply systems lines are inevitable due to the need to ensure the minimum level of the voltage of electric rolling on long cantilever sections of the traction network and for them it is necessary usage of the vector method of determining the amount of electricity.

\section{REFERENCES}

1. Energetichna strategija Ukrzaliznici na period do 2015 r. $i$ na perspektivu do $2020 \mathrm{r}$. Zatv. derzhavnoju administracieju zaliznichnogo transportu Ukrainu 26.11.2013 r. [Energy Strategy Railways for the period up to 2015 and for the future by 2020. Approved by State Administration of Railway Transport of Ukraine 11.26.2013]. Kyiv, 2013. 104 p. (Ukr).

2. Kornienko V.V., Kotel'nikov A.V., Domanskyi V.T. Elektrifikacija zheleznyh dorog. Mirovye tendencii i perspektivy (Analiticheskij obzor) [Electrification of railways. Global trends and perspectives (Analytical review)]. Kyiv, Transport of Ukraine Publ., 2004. 196 p. (Rus).

3. Markvard K.G. Elektrosnabzhenie elektrificirovannyh zheleznyh dorog [Power supply of electrified railways]. Moscow, Transport Publ., 1982. 528 p. (Rus).

4. Rene Pelis'e. Energeticheskie sistemy [Energy Systems]. Moscow, Higher School Publ., 1982. 568 p. (Rus).

5. Domanskyi I.V. Osnovi energoefektivnosti elektrichnih sistem z tjagovimi navantazhennjami: monografija [Basics of energy efficiency of electrical systems with traction load: monograph]. Kharkiv, TOV «Tsentr informatsiyi transportu Ukrayiny» Publ., 2016. 224 p. (Ukr).

6. Domanskiy I.V. Modes in electrical systems with mobile AC traction substations. Vestnik of Railway Research Institute, 2016, vol.75, no.1. pp. 19-25. (Rus).

7. Domanskyi I.V. Electrification of railways - source of energy efficiency of process transportations. Railway Transport of Ukraine, 2014, no. 1, pp. 19-23, 31-33. (Ukr).

8. Pravyla ulashtuvannia systemy tiahovoho elektropostachannia zaliznyts Ukrainy. № TsE-0009: Zatv. Nakaz Ukrzaliznytsi 24.12.2004 r., № 1010-TsZ. / Min-vo transp. ta zviazku Ukrainy [Terms ordering system Traction Power railways of Ukraine. Number IS-0009: approved. Order Railways year 24.12.2004., № 1010-CH. Ministry of Transport and Communications of Ukraine]. Kyiv, 2005. 80 p. (Ukr).

9. Domansky I.V. System analysis of external power supply of railways traction substation. Electrical Engineering \& Electromechanics, 2013, no.3, pp. 54-63. (Ukr). doi: 10.20998/2074-272X.2013.3.10.

10. Shidlovskij A.K., Kuznetsov V.G., Nikolaenko V.G. Optimizacija nesimmetrichny rezhimov sistem elektrosnabzhenija [Optimization of asymmetrical modes of power supply systems]. Kiev, Naukova Dumka Publ., 1987. 174 p. (Rus).

11. Zhelezko Yu.S. Poteri elektrojenergii. Reaktivnaja moshhnost'. Kachestvo elektrojenergii [Loss of electricity. Reactive power. Power quality]. Moscow, ENAS Publ., 2009. 456 p. (Rus). 
12. Borodulin B.M., German L.A., Nikolaev G.A. Kondensatornye ustanovki elektrificirovannyh zheleznyh dorog [Condenser units for electrified railways]. Moscow, Transport Publ., 1983. 183 p. (Rus).

13. German L.A., Goncharenko V.P. Modern longitudinal capacitive compensation scheme in the traction power supply. Bulletin of Rostov State Transport University, 2013. no.2. pp. 12-17. (Rus).

14. Domanskyi I.V. Modes of operation of the system of traction power $\mathrm{AC}$ using reactive power compensation devices. Electrical Engineering \& Electromechanics, 2015, no.3, pp. 5966. (Rus). doi: 10.20998/2074-272X.2015.3.09.

15. German L.A., Serebryakov A.S., Maksimova A.A. Filter compensating installation in AC traction networks. Vestnik of Railway Research Institute, 2016. no.1. pp. 26-34. (Rus).

Received 29.11.2016
V.O. Bondarenko ${ }^{1}$, Doctor of Technical Science, Professor, I.V. Domanskyi ${ }^{1}$, Candidate of Technical Science,

G.N. Kostin',

${ }^{1}$ National Technical University «Kharkiv Polytechnic Institute», 21, Kyrpychova Str., Kharkiv, 61002, Ukraine,

e-mail: dvt.nord@mail.ru

${ }^{2}$ Kharkiv regional department of the branch «Energosbyt» of Public Joint Stock Company «Ukrainian Railway»,

7, Konareva Str., Kharkiv, 61052, Ukraine,

e-mail: ee_ugd_kh@ukr.net

How to cite this article:

Bondarenko V.O., Domanskyi I.V., Kostin G.N. Analysis of energy efficiency of operating modes of electrical systems with the traction loads. Electrical engineering \& electromechanics, 2017, no.1, pp. 54-62. doi: 10.20998/2074272X.2017.1.09. 